Tropical Journal of Pharmaceutical Research March 2016; 15 (3): 583-589

ISSN: $1596-5996$ (print); 1596-9827 (electronic)

(C) Pharmacotherapy Group, Faculty of Pharmacy, University of Benin, Benin City, 300001 Nigeria.

All rights reserved.

Available online at http://www.tjpr.org

Original Research Article

http://dx.doi.org/10.4314/tjpr.v15i3.21

\title{
Ursolic Acid Florotriazole Treatment Causes Inhibition of Squamous Cell Carcinoma through Fas Signaling Pathway
}

\author{
Jing-Chun Huang ${ }^{1 *}$, Cheng-Gang Zhang ${ }^{2}$, Yi-Yun Zhao ${ }^{1}$ and Shi-Yi Zhao ${ }^{3}$ \\ ${ }^{1}$ Department of Stomatology, ${ }^{2}$ Department of Neurosurgery, ${ }^{3}$ Department of Medical Oncology, The Third Hospital Of Jinan, \\ Jinan 250132, China
}

*For correspondence: Email: huangjcoral@gmail.com; Tel/Fax: 0086-531-88985434

Revised accepted: 16 February 2016

\begin{abstract}
Purpose: To investigate the effect of ursolic acid florotriazole (UFT), on SCC-15 oral squamous cancer cells.

Methods: Confocal laser microscope with a $490 \mathrm{~nm}$ argon laser was used to record the fluorescence of the cells and capture the images. Flow cytometry and Cell Quest program were used to analyze the DNA content of the stained cells. Apoptosis was characterized by YO-PRO-1 staining.

Results: Treatment of SCC-15 cells with UFT for $48 \mathrm{~h}$ significantly reduced cell viability in a dosedependent manner. At $20 \mu \mathrm{g} / \mathrm{mL}$ concentration of UFT, SCC-15, cell viability was reduced to $19 \%$ compared to $100 \%$ in the untreated cells $(p=0.0002)$. UFT treatment enhanced the proportion of apoptotic cells which was evident from YO-PRO-1 staining. In UFT-treated cultures, the population of cells in sub-G1 phase increased to $38.54 \%$ compared to $7.32 \%$ for control after $48 \mathrm{~h}$. Expression of Fas in UFT-treated cells was also higher $(p=0.0002)$ than in untreated cells. In C3H/HeJ mice, administration of UFT daily for 14 days caused a significant $(p=0.0002)$ reduction in tumor volume and weight after 30 days of SCC-15 carcinoma cell administration.

Conclusion: UFT treatment inhibits viability and induces apoptosis in squamous cell carcinoma cells through suppression of Fas expression. Therefore, UFT may be useful for the treatment of squamous cell cancer.
\end{abstract}

Keywords: Ursolic acid florotriazole, Squamous cell cancer, Fas expression, Tumor volume, Cell viability, Apoptosis

Tropical Journal of Pharmaceutical Research is indexed by Science Citation Index (SciSearch), Scopus, International Pharmaceutical Abstract, Chemical Abstracts, Embase, Index Copernicus, EBSCO, African Index Medicus, JournalSeek, Journal Citation Reports/Science Edition, Directory of Open Access Journals (DOAJ), African Journal Online, Bioline International, Open-J-Gate and Pharmacy Abstracts

\section{INTRODUCTION}

Squamous cell carcinoma is the commonly observed malignant tumor of mucosa lining of the oral cavity. In Korea squamous cell carcinoma accounts for more than $90 \%$ of the detected malignant tumors of the oral cavity [1]. Despite advancement in the fields of chemotherapy, radiation therapy and surgery, the prognosis of oral squamous cell cancer patients remains poor [2]. The five year survival rate of oral squamous cell cancer patients has been observed to be 50
$\%$ [2]. Taking into consideration the poor survival rate, the discovery of drugs for the treatment of patients with squamous cell carcinoma is desperately required.

Apoptosis, the programmed and controlled process of cell death is regulated by both internal as well as external signals. It plays an important role in the development and maintenance of multicellular organisms by eliminating unwanted cells from the body [3]. Apoptotic cells are characterized by morphological alterations 
including, decreased cell and nucleus sizes, blebbing of plasma membrane, condensation of chromatin and DNA fragmentation [4]. Induction of apoptosis in carcinoma cells by treatment with chemotherapeutic agents is a promising strategy for cancer treatment $[5,6]$.

Ursolic acid (UA), belonging to the terpenoid family of natural products is a pentacyclic molecule abundantly present in the plant kingdom [7-10]. It is a biologically active compound and has medicinal importance in traditional Chinese medicine for the clinical treatment of various diseases. UA exhibits a broad spectrum of activities including, as antiinflammatory, antiviral, antioxidant, hepatoprotective, cytotoxic, antitumor, antiangiogenesis, and anti-metastatic activities [11]. It has also been demonstrated that UA causes inhibition of colon carcinoma cell proliferation and induces apoptosis [12,13-15].

It was reported that the triazole analogs of UA are more potent compared to the parent compound. In the present study, the effect of ursolic acid floro triazole (UFT) on oral squamous cancer was investigated. The results revealed a significant reduction in cell viability, induction of apoptosis, cell cycle arrest and reduction in tumor weight and volume in vivo.

\section{EXPERIMENTAL}

\section{Drug and chemical}

Ursolic acid florotriazole (UFT) was synthesized using a previously reported procedure from the parent ursolic acid using reported procedure [13]. UFT was dissolved in DMSO to prepare the stock solution and stored at $-20{ }^{\circ} \mathrm{C}$.

\section{Animals}

Female $\mathrm{C} 3 \mathrm{H} / \mathrm{HeN}$ mice (8 weeks old) were purchased from the Laboratory Animal Center, Third Military Medical University (Chongqing, China). The animals were housed under $12 \mathrm{~h}$ light and dark cycle in pathogen-free environment, with access to water and food ad libitum.

All the animal experiments were performed according to the Kyung Hee University Institutional Animal Care and Use Committee guidelines. The study was approved by the ethics committee of Kyung Hee University Institutional Animal Care and Use (approval reference no. 012-47-KHI.

\section{Cell culture}

SCC-15 human squamous cell carcinoma cell line was purchased from The Cell Bank of Type Culture Collection of Chinese Academy of Sciences, Shanghai Institute of Cell Biology (Shanghai, China). The cells were maintained at $37{ }^{\circ} \mathrm{C}$ in an atmosphere of $5 \% \mathrm{CO}_{2}$ in RPMI1640 medium (Thermo Fisher Scientific Inc., Waltham, MA, USA). The study was approved by the Ethics Committee of Kyung Hee University (Yongin, Korea).

\section{MTT assay}

Into the 96-well flat bottom multiplates (BD Falcon, Franklin, $\mathrm{NJ}$ ) cells at a density of $2.5 \mathrm{x}$ $10^{5}$ cells per well were distributed. To each of the well different concentration of UFT was added and incubated for $48 \mathrm{~h}$. MTT (Sigma-Aldrich, St. Louis, MO, USA) solution ( $10 \mu \mathrm{L})$ was added to each well and the plates were incubated for $4 \mathrm{~h}$ at $37{ }^{\circ} \mathrm{C}$ in $5 \% \mathrm{CO}_{2}$ incubator. Formazan crystals were dissolved by adding $0.04 \mathrm{~N} \mathrm{HCl}$ in 2-propanol $(100 \mu \mathrm{L})$. The microplate reader (MPR-A4i; Tosoh Corporation, Tokyo, Japan) was used to measure absorption at $570 \mathrm{~nm}$. All the measurements were carried out in triplicate.

\section{Confocal microscopy}

SCC- 15 cells at a density of $2 \times 10^{6}$ cells per well were distributed onto 6-well plates (Nunc A/S) containing RPMI-1640 supplemented with $2 \%$ FBS. Following $24 \mathrm{~h}$ incubation, the cells were treated with a range of UFT concentrations $(2,5$, 10,20 and $30 \mu \mathrm{g} / \mathrm{mL}$ ). After $48 \mathrm{~h}$, the cells were washed twice with ice-cold PBS, treated with 20 $\mu \mathrm{L}$ PBS and subsequently stained for $30 \mathrm{~min}$ with $0.2 \mu \mathrm{M}$ YO-PRO-1 (Molecular Probes Inc., Eugene, OR, USA) dye. The confocal laser microscope (LSM 510 Meta; Carl Zeiss, Oberkochen, Germany) with a $490 \mathrm{~nm}$ argon laser was used to record the fluorescence of the cells and capture the images.

\section{Cell cycle analysis}

In $100 \mathrm{~mm}$ culture dishes, SCC-15 cells were distributed at a density of $2 \times 10^{5}$ cells per well and incubated with various concentrations of UFT for $48 \mathrm{~h}$. The cells were then harvested, centrifuged for $10 \mathrm{~min}$ at $500 \times \mathrm{g}$ and subsequently rinsed in ice-cold PBS. The cells were fixed in $70 \%$ ethyl alcohol and stored for 2 $\mathrm{h}$ at $-20{ }^{\circ} \mathrm{C}$. Followed PBS washing, the cells were put in $200 \mu \mathrm{L} \mathrm{Pl/RNase} \mathrm{Staining} \mathrm{Buffer} \mathrm{(BD}$ Biosciences) for $1 \mathrm{~h}$ under dark conditions. FACSVantage SE flow cytometry system and CellQuest program (BD Biosciences) were used 
for the analysis of DNA content of the stained cells.

\section{Reverse transcription (RT)-PCR}

The cells were cultured in medium containing UFT followed by RNA extraction using Isogen systems reagents (Nippon Gene Co., Ltd., Tokyo, Japan). Following denaturation by heating at $60{ }^{\circ} \mathrm{C}$ for $30 \mathrm{~min}$ using $500 \mathrm{pmol}$ oligo(dT) primer, RNA was reverse-transcribed to cDNA. The reverse-transcription solution comprised of Moloney murine leukemia virus reverse transcriptase (Invitrogen Japan K. K., Tokyo, Japan), $75 \mathrm{~mm} \mathrm{KCl}, 50 \mathrm{~mm}$ Tris- $\mathrm{HCl}$ (pH 8.3), 3 $\mathrm{mm} \mathrm{MgCl}, 0.01 \mathrm{M}$ DTT, $0.5 \mathrm{~mm}$ of each dNTP and 16 units RNasin ${ }^{\circledR}$ (Promega Corporation, Madison, WI, USA). Quantitative PCR and BI Prism 7700 Sequence Detector (TaqMan; PE Biosystems Japan, Tokyo, Japan) were used for the amplification of cDNA. The reaction was performed in a $50 \mu \mathrm{L}$ reaction mixture containing $200 \mathrm{nM}$ forward and reverse primers, $100 \mathrm{nM}$ probe specific for the targeted CDNA and TaqMan Universal Master mix (PE Biosys- tems Japan). The data were examined using Sequence Detection software (PE Biosystems Japan). The primers and probes for amplifying Fas were purchased from PE Biosystems Japan. Target gene expression levels were standardized to the internal standard gene expression levels. The relative expression levels of Fas in the UFTtreated cells were compared with the levels in the untreated cells. Enhanced chemiluminescence system was used for visualization of immunoreactive bands.

\section{Tumor growth in in vivo SCC-15 animal model}

To establish an in vivo SCC-15 animal model, $2 \mathrm{x}$ $10^{5}$ SCC-15 cells in $100 \mu \mathrm{L}$ PBS were subcutaneously injected into the right flank of the $\mathrm{C} 3 \mathrm{H} / \mathrm{HeJ}$ mice. After five days, when the tumors formed visible masses, the animals were divided into two groups, each containing 5 mice. The animals in treatment group were injected intraperitoneally $20 \mathrm{mg} / \mathrm{kg}$ body weight of UFT daily in the morning for 15 days whereas the animals in control group received PBS. On day 30 following carcinoma cell administration, the animals were euthanized using $\mathrm{CO}_{2}$ and the tumors were extracted and weighed. The volume of the tumor was determined after measurement of tumor dimensions using a caliper.

\section{Statistical analysis}

For the purpose of statistical analysis, MannWhitney $U$ test was used. Student's t-test was used for statistical analysis of the effect of UFT on cancer cell proliferation and the alteration of mRNA expression in vitro. $P<0.05$ was considered to indicate a statistically significant difference.

\section{RESULTS}

\section{Suppression of SCC-15 cell viability by UFT}

The effect of various concentrations $(0,2,5,10$, 15,20 and $30 \mu \mathrm{g} / \mathrm{mL}$ ) of UFT on the viability of SCC- 15 cells was evaluated by MTT assay. The results revealed a concentration dependent reduction in the viability of SCC-15 cells on treatment with UFT for $48 \mathrm{~h}$. Among the various concentrations of UFT tested, the reduction in cell viability was maximum at $20 \mu \mathrm{g} / \mathrm{mL}$ concentration after 48 h. At $20 \mu \mathrm{g} / \mathrm{mL}$ concentration of UFT, SCC-15 cell viability was reduced to $19 \%$ compared to the untreated cells $(p=0.0002$, Figure 1$)$.

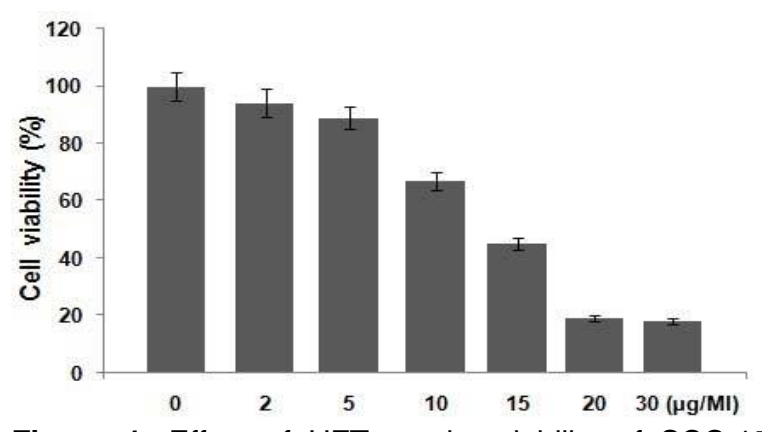

Figure 1: Effect of UFT on the viability of SCC-15 cells. The cells after treatment with $2,5,10,15,20$ and $30 \mu \mathrm{g} / \mathrm{mL}$ concentrations of UFT for $48 \mathrm{~h}$ were analyzed for viability using MTT assay. The data expressed are the mean \pm standard deviation for three experiments. UFT, stands for ursolic acid florotriazole

\section{Induction of apoptosis in SCC-15 cells by UFT}

Induction of apoptosis in SCC-15 cells by UFT treatment was examined using YO-PRO-1 dye followed by confocal microscopy. The results showed a significant increase in the proportion of apoptotic cells with increase in the concentration of UFT from 5 to $20 \mu \mathrm{g} / \mathrm{mL}$ (Figure 2).

\section{UFT increased the number of cells in sub-G1 phase}

Analysis of cell cycle using flow cytometry after $\mathrm{PI}$ staining revealed a significant increase in the proportion of cells in sub-G1 phase (Figure 3A). UFT treatment at $20 \mu \mathrm{g} / \mathrm{ml}$ increased the proportion of cells in sub-G1 phase to $38.54 \%$ compared to $7.32 \%$ in the control cells after 48 h. 


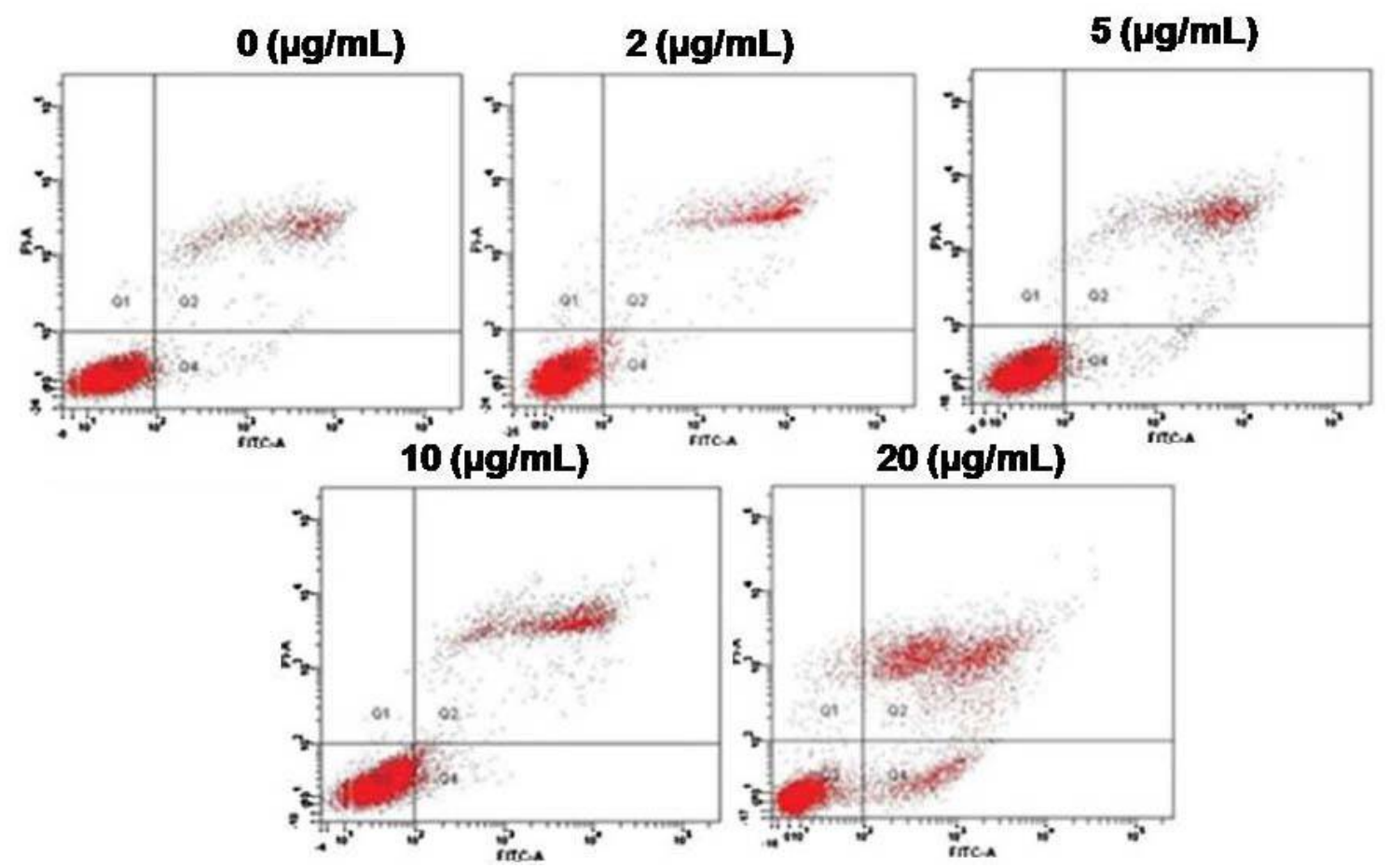

Figure 2: Effect of UFT on the induction of apoptosis in SCC-15 cells using YO-PRO-1 staining. The cells following 2, 5, 10, 15 and $20 \mu \mathrm{g} / \mathrm{mL}$ concentrations of UFT treatment were stained with YO-PRO-1 and imaged by confocal microscope. UFT, stands for ursolic acid florotriazole

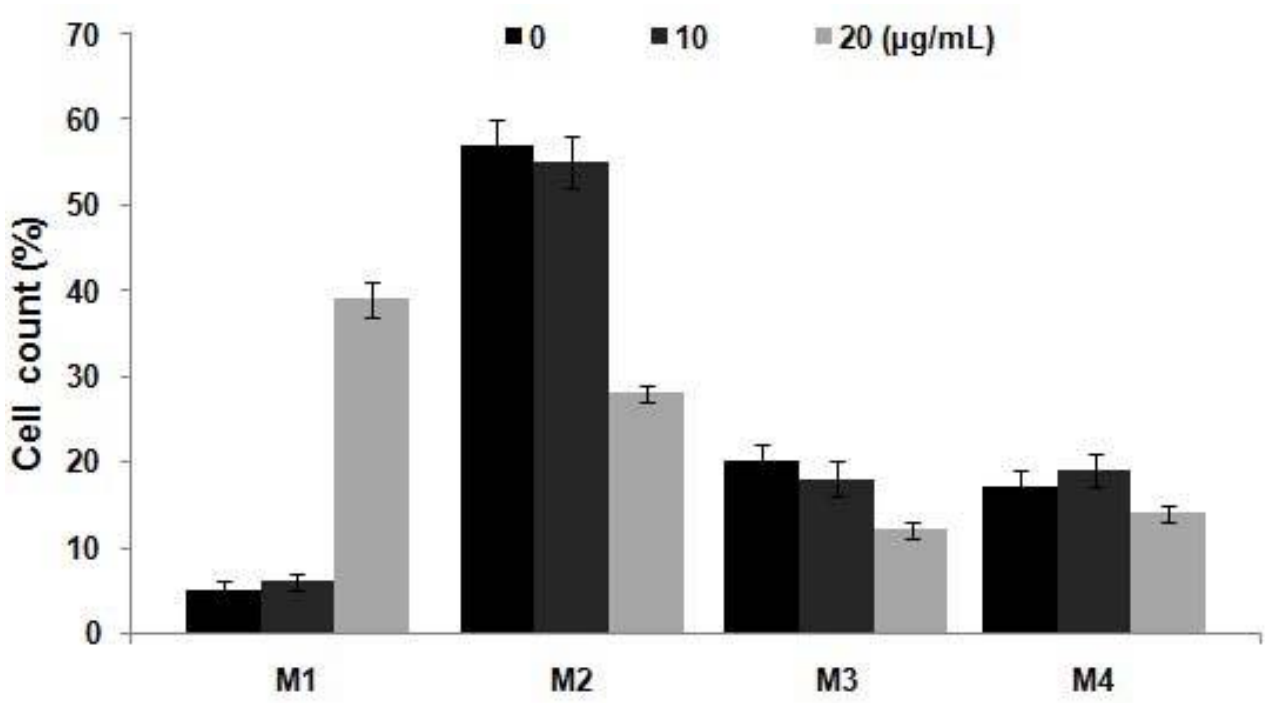

Figure 3: Analysis of SCC-15 cell cycle by flow cytometric analysis. UFT treatment increased the population of SCC-15 cells in sub-G1 phase of cell cycle. DNA content of SCC-15 cells after treatment with $20 \mu \mathrm{g} / \mathrm{mL}$ of UFT for $48 \mathrm{~h}$ were analyzed by flow cytometry following propidium iodide staining

\section{Effect of UFT treatment on the expression of Fas gene in SCC-15 cells}

Expression of Fas gene in SCC-15 cells was determined by RT-PCR. The results showed a significant increase in the expression of Fas on treatment with $20 \mu \mathrm{g} / \mathrm{mL}$ concentration of UFT compared to that of untreated cells (Figure 4). The increase in the expression of Fas by UFT treatment was further confirmed using western blot analysis (Figure 4). These data indicate that UFT increases the expression of Fas in SCC-15 cells.

\section{UFT treatment inhibits tumor growth in an SCC-15 animal model}

The antitumor activity of UFT treatment was examined in an SCC-15 animal model using $\mathrm{C} 3 \mathrm{H} / \mathrm{HeJ}$ mice. At five days after subcutaneous 
implantation of SCC-15 cells, the mean tumor volume was $\sim 10 \mathrm{~mm}^{3}$. In the control (PBStreated) group, the tumors grew rapidly and reached an average volume of $501 \pm 43.9 \mathrm{~mm}^{3}$ (mean \pm SD) on day 14 after inoculation with SCC-15 cells (Figure 5A). The mean size of the primary tumor in animals treated with $10 \mathrm{mg} / \mathrm{kg}$
UFT was determined to be $202 \pm 20.2 \mathrm{~mm}^{3}$ at 14 days. Similarly, the mean tumor weight for the animals treated with $10 \mathrm{mg} / \mathrm{kg}$ UFT $46.2 \%$ of that in the control group (Figure 5B). Together, these results indicate that UFT inhibited tumor growth in the SCC-15 animal model.

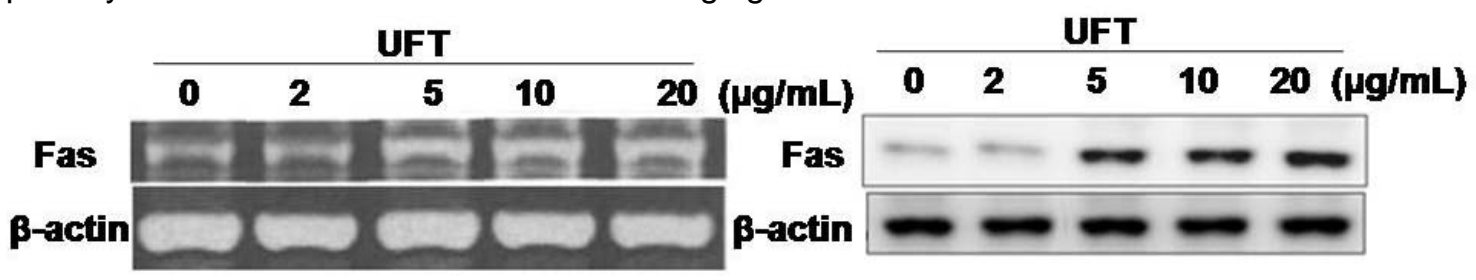

Figure 4: Effect of UFT on the Fas expression. The expression of Fas gene was analyzed by semi-quantitative reverse transcription-polymerase chain reaction whereas that of Fas protein by western blots analysis. The proteins were extracted from SCC-15 cells after treatment with $20 \mu \mathrm{g} / \mathrm{mL}$ UFT for $48 \mathrm{~h}$. $\beta$-actin was used as an internal control

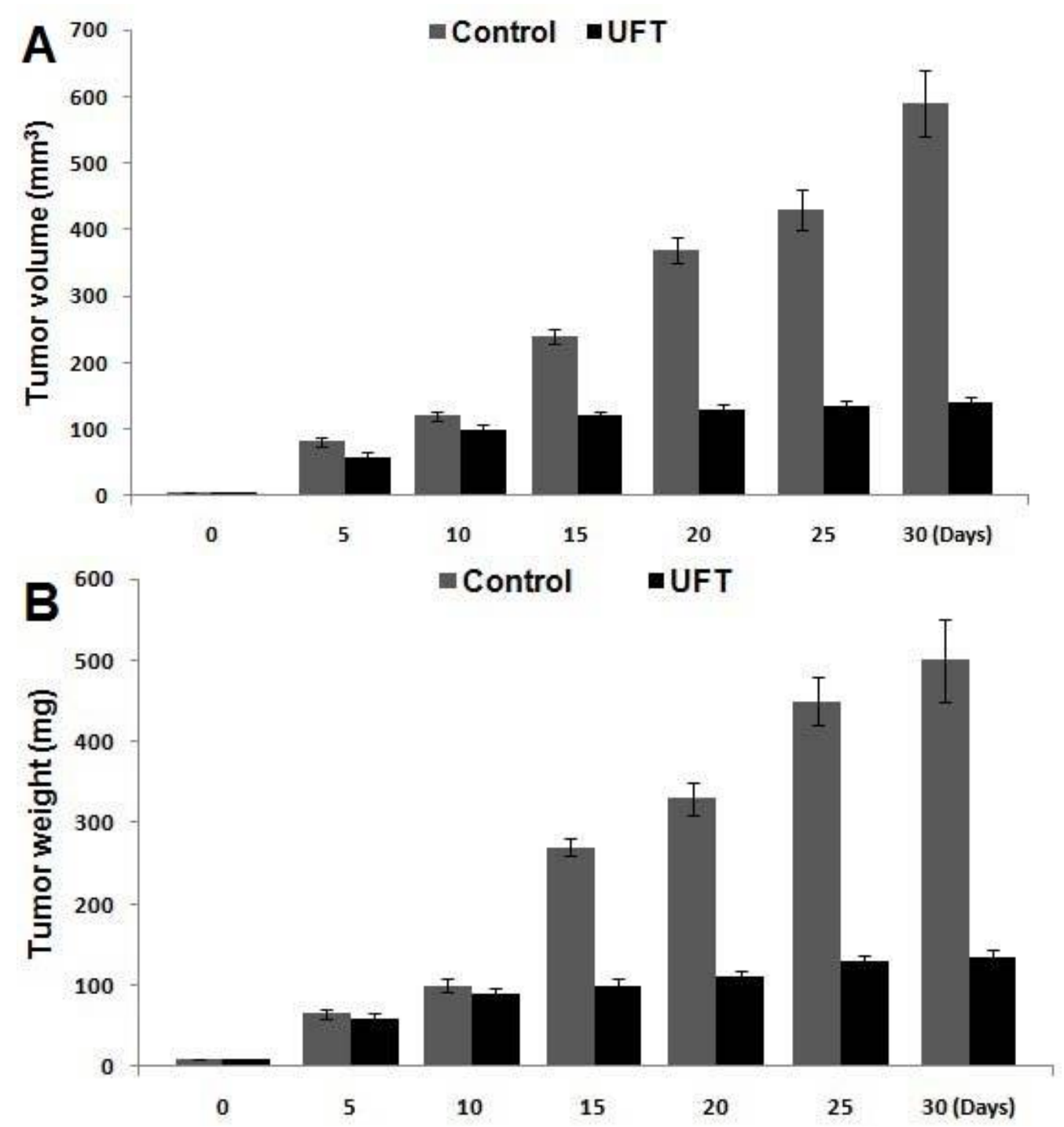

Figure 5: UFT treatment inhibits the growth and weight of tumor in SCC-15 animal model. $2 \times 105$ SCC-15 cells in PBS were administered into the right flanks of $\mathrm{C} 3 \mathrm{H} / \mathrm{HeJ}$ mice. The mice were treated with UFT for 15 days and were then sacrificed after 30 days. The volume and weight of tumor was measured. The data expressed are the mean \pm standard deviation of triplicate experiments 


\section{DISCUSSION}

The present study demonstrates effect of UFT on the cell viability, induction of apoptosis and the mechanism underlying the in vitro inhibition of oral squamous cancer cells as well as in vivo mouse model. It was observed that UFT treatment inhibited SCC-15 cell viability, induced apoptosis, and increased the proportion of cells in sub-G1 phase. In addition, the tumor volume and weight in the UFT-treated mice were also reduced significantly compared to the untreated mice.

Inhibition of the viability of carcinoma cell lines by chemotherapeutic agents can be a promising strategy for the treatment of cancers. The results from the present study showed that UFT exhibited a concentration dependent inhibitory effect on the viability of SCC-15 cells following exposition for $48 \mathrm{~h}$. UFT treatment increased the proportion of apoptotic cells significantly compared to the untreated cells. Analysis of cell cycle revealed a marked increase in the population of cells in sub-G1 phase with increase in the concentration of UFT to $20 \mu \mathrm{g} / \mathrm{mL}$. It is reported that Fas exhibits a vital role in the induction of cell apoptosis in various types of carcinoma cells through the caspase activation pathway [16]. UFT treatment for $48 \mathrm{~h}$ caused enhancement in the expression of Fas gene in SCC-15 cells significantly compared to the untreated control cells. Thus, UFT treatment leads to apoptosis in SCC-15 cells via Fas signaling pathway activation. In the present study, the antitumor activity of UFT was also investigated in a SCC-15 animal model using $\mathrm{C} 3 \mathrm{H} / \mathrm{HeJ}$ mice. Reduction in the tumor volume and weight has been observed in various types of mouse xenograft models including, renal and prostate carcinoma $[17,18]$. In the present study, it was observed that UFT treatment caused a significant suppression in the volume and weight of tumor in SCC-15 animal model.

\section{CONCLUSION}

The results from the present study reveal that UFT inhibited cell viability, induced apoptosis of oral squamous cell cancer cells, and suppressed tumor growth in vivo through Fas signaling pathway. Thus, UFT is a potent candidate for the treatment of squamous cell cancer.

\section{REFERENCES}

1. Kim KM, Kim YM, Shim YS. Study Group of Korean Society of Head and Neck Surgerons: Epidemiologic survey of head and neck cancers in Korea. $J$ Korean Med Sci 2003; 18: 80-87.

2. Parkin DM. Global cancer statistics in the year 2000. Lancet Oncol 2001; 2: 533-543.

3. Raff MC, Barres BA, Burne JF, Coles HS, Ishizaki $Y$, Jacobson MD. Programmed cell death and the control of cell survival: Lessons from the nervous system. Science 1993; 262: 695-700.

4. Wyllie AH, Kerr JF, Currie AR. Cell death: The significance of apoptosis. Int Rev Cytol 1980; 68: 251 306.

5. Kaufmann SH, Earnshaw WC. Induction of apoptosis by cancer chemotherapy. Exp Cell Res 2000; 256: 42-49.

6. King KL, Cidlowski JA. Cell cycle regulation and apoptosis. Annu Rev Physiol 1998; 60: 601-617.

7. Lin JM, Wei LH, Xu W, Hong ZF, Liu XX, Peng J. Effect of Hedyotis Diffusa Willd extract on tumor angiogenesis. Mol Med Rep 2011; 4: 1283-1288.

8. Peng J, Chen YQ, Lin JM, Zhuang QC, Xu W, Hong ZF, Sferra TJ. Patrinia Scabiosaefolia extract suppresses proliferation and promotes apoptosis by inhibiting STAT3 pathway in human multiple myeloma cells. Mol Med Rep 2011; 4: 313-318.

9. Wei LH, Chen YQ, Lin JM, Zhao JY, Chen XZ, Xu W, Liu $X X$, Sferra TJ, Peng J. Scutellaria Barbata D. Don induces apoptosis of human colon carcinoma cell via activation of the mitochondrion-dependent pathway. $J$ Med Plants Res 2011; 5: 1962-1970.

10. Zheng $L P$, Chen $Y Q$, Lin $W$, Zhuang $Q C$, Chen $X Z, X u$ $W$, Liu XX, Peng J, Sferra TJ. Spica Prunellae extract promotes mitochondrion-dependent apoptosis in a human colon carcinoma cell line. Afr $J$ Pharm Pharmacol 2011; 5: 327-335.

11. Ikeda $Y$, Murakami A, Ohigashi $H$. Ursolic acid: an antiand pro-inflammatory triterpenoid. Mol Nutr Food Res 2008; 52: 26-42.

12. Cook KM, Figg WD. Angiogenesis inhibitors: current strategies and future prospects. CA Cancer J Clin 2010; 60: 222-243.

13. Andersson D, Liu JJ, Nilsson A, Duan RD. Ursolic acid inhibits proliferation and stimulates apoptosis in HT29 cells following activation of alkaline sphingomyelinase. Anticancer Res 2003; 23: 3317-3322.

14. Prasad S, Yadav VR, Sung B, Reuter S, Kannappan R, Deorukhkar A, Diagaradjane $P$, Wei $C$, Baladandayuthapani V, Krishnan S, Guha S, Aggarwal $B B$. Ursolic acid inhibits growth and metastasis of human colorectal cancer in an orthotopic nude mouse model by targeting multiple cell signaling pathways: chemosensitization with capecitabine. Clin Cancer Res 2012; 18: 4942-4953.

15. Pola R, Ling LE, Silver $M$, Corbley MJ, Kearney $M$, Pepinsky RB, Shapiro R, Taylor FR, Baker DP, Asahara $T$. The morphogen Sonic hedgehog is an indirect angiogenic agent upregulating two families of angiogenic growth factors. Nat Med 2001; 7: 706-711.

16. López-Hernández FJ, Ortiz MA, Piedrafita FJ. The extrinsic and intrinsic apoptotic pathways are

Trop J Pharm Res, March 2016; 15(3): 588 
Huang et al

differentially affected by temperature upstream of mitochondrial damage. Apoptosis 2006; 11: 1339-1347.

17. Maeshima $Y$, Colorado PC, Torre A, Holthaus KA, Grunkemeyer JA, Ericksen MB, Hopfer $H$, Xiao $Y$, Stillman IE, Kalluri R. Distinct antitumor properties of a type IV collagen domain derived from basement membrane. J Biol Chem 2000; 275: 21340-21348.
18. Maeshima $Y$, Manfredi $M$, Reimer $C$, Holthaus $K A$, Hopfer $H$, Chandamuri BR, Kharbanda S, Kalluri $R$. Identification of the anti-angiogenic site within vascular basement membrane-derived tumstatin. $\mathrm{J}$ Biol Chem 2001; 276: 15240-15248. 